\title{
REAKSI PASAR ATAS HASIL PEMILU PRESIDEN 2014 (Studi Pada Emiten yang Listing di Jakarta Islamic Index)")
}

\author{
Astuti Kurniawati \\ Mahasiswa Program Studi S1 Ekonomi Islam-Fakultas Ekonomi dan Bisnis-Universitas Airlangga \\ Email: ast.astkur@gmail.com \\ Leo Herlambang \\ Departemen Ekonomi Syariah-Fakultas Ekonomi dan Bisnis-Universitas Airlangga \\ Email: leo.herlambang@gmail.com
}

\begin{abstract}
:
The results of the presidential elections can provide a signal for investors to make decisions to invest. The purpose of this study was to determine the market reaction to the results of the presidential elections. Market reaction in this study is indicated by the presence of abnormal returns around the announcement date and the difference in trading volume activity before and after the announcement. This study is a quantitative research by using event study method with 25 issuers that listed on the Jakarta Islamic Index during the study period. The study was conducted during the 121 days consisting of 100-day estimation period and 21 day observation period. Statistical calculation in this study showed insignificant results both in the AAR and TVR. It means there is no impact from the announcement of the presidential election's result because the investors may have been anticipating the result of the announcement.
\end{abstract}

\section{Keywords: The result of presidential election, Abnormal Return, Trading Volume Activity}

\section{PENDAHULUAN}

Islam merupakan agama yang mengatur kehidupan manusia secara menyeluruh, mulai dari hubungan antara manusia dengan Tuhannya yang diatur dalam hukum ibadah, hingga hubungan manusia dengan manusia, hubungan manusia dengan lingkungan, serta dengan dirinya sendiri yang diatur dalam hukum muamalah. Investasi merupakan bagian dari kegiatan ekonomi yang diatur dalam hukum muamalah agar dalam pelaksanaannya tetap berada dalam koridor yang diperbolehkan oleh Islam.

Keputusan investor untuk
melakukan investasi salah satunya
dipengaruhi oleh perubahan pada
atmosfer politik, yaitu salah satu jenis risiko sistematis yang dapat mempengaruhi semua saham dan tidak dapat dihilangkan dengan cara diversifikasi saham. Perubahan pada atmosfer politik suatu negara salah satunya disebabkan oleh adanya event politik berskala nasional, seperti pemilu presiden.

Penelitian ini fokus pada calon presiden nomor urut dua yang saat ini telah berstatus sebagai presiden terpilih, yaitu Joko Widodo. Hal ini dikarenakan Joko Widodo merupakan calon yang paling banyak disorot oleh media dengan isu yang menyatakan adanya keterkaitan pencalonan dirinya dengan semakin tingginya jumlah hot money yang masuk ke Indonesia yang menyebabkan bergejolaknya harga saham di pasar modal.

\footnotetext{
1) Jurnal ini merupakan bagian dari skripsi yang ditulis oleh Astuti Kurniawati, NIM: 041114035 , yang diuji pada 09 Februari 2015.
} 
Bergejolaknya harga saham di pasar modal ditunjukkan oleh pergerakan IHSG (Indeks Harga Saham Gabungan) di sekitar waktu-waktu penting yang berhubungan dengan Joko Widodo dan Pemilu Presiden. BBC (British Broadcasting Corporation) diperoleh dari www.bbc.co.uk pada tanggal 14 Maret 2014 menyatakan bahwa seiring dengan pengumuman pencapresan Joko Widodo, Indeks Harga Saham Gabungan (IHSG), pada akhir pedagangan melonjak hingga 142 poin atau sekitar 3\% menjadi 4869, mencapai titik tertinggi setidaknya sejak sembilan bulan terakhir. Berlangsungnya pemilu presiden pada tanggal 9 Juli 2014 juga direspon positif oleh pergerakan IHSG dimana pada tanggal 8 Juli 2014 IHSG menyentuh titik 5024,71 dan pada tanggal 10 Juli 2014 meningkat lagi menjadi 5098,01. Hasil real count Pemilu Presiden secara resmi diumumkan pada tanggal 22 Juli 2014 yang menyatakan kemenangan berada di pihak Joko Widodo dan direspon negatif oleh IHSG yang turun sebesar 43.6 poin. Hal ini kemungkinan disebabkan oleh mundurnya calon presiden nomor urut satu sesaat sebelum pengumuman hasil pemilu. Setelah dilakukan sidang penghitungan suara ulang, pada tanggal 21 Agustus 2014, Joko Widodo kembali ditetapkan sebagai Presiden terpilih Indonesia periode 2014-2019. Kejadian ini direspon positif oleh IHSG dengan melonjaknya angka IHSG menjadi 5206, 14 dan menjadi angka tertinggi yang berhasil dicapai IHSG di titik-titik peristiwa penting sekitar Pemilu Presiden 2014.

Kondisi di atas menunjukkan adanya pengaruh dari peristiwa politik bertaraf nasional seperti Pemilu Presiden terhadap reaksi pasar modal di Indonesia. Di sisi lain, perubahan-perubahan yang terjadi di pasar modal dapat mengindikasikan adanya aksi dari para spekulan yang memanfaatkan keadaan politik Indonesia dan aksi para spekulan tersebut telah jelas dilarang dalam syariah Islam karena sifatnya yang mirip dengan gambling atau judi. Hal ini sesuai dengan firman Allah SWT dalam Al-Qur'an surah Al-Maidah ayat 90 :

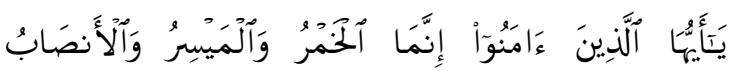

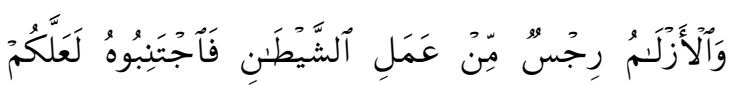
تُفْلحُونَ

Artinya: "Hai orang-orang yang beriman, sesungguhnya (meminum) khamar, berjudi, (berkorban untuk) berhala, mengundi nasib dengan panah, adalah termasuk perbuatan syaitan. Maka jauhilah perbuatan-perbuatan itu agar kamu mendapat keberuntungan."

Ayat di atas menjelaskan tentang perintah untuk menjauhi judi dan mengundi nasib dengan panah yang dalam konteks ini dapat disamakan dengan perbuatan spekulatif yang bersifat untung rugi. Oleh karena itu, penelitian yang dilakukan lebih spesifik melihat reaksi pasar saham yang masuk dalam kriteria sesuai syariah yang listing di Jakarta Islamic Index (JII).

Reaksi pasar atas sebuah peristiwa dalam penelitian ini ditunjukkan dengan 
adanya abnormal return di sekitar tanggal peristiwa dan adanya perubahan trading volume activity sebelum dan sesudah tanggal terjadinya peristiwa.

Berdasarkan uraian di atas maka rumusan masalah yang diajukan dalam penelitian ini adalah Apakah terdapat Average Abnormal Return (AAR) yang signifikan di sekitar tanggal penetapan Joko Widodo sebagai Presiden terpilih Indonesia pada perusahaan yang listing di Jakarta Islamic Index? dan apakah terdapat perbedaan Abnormal Trading Volume Activity (ATVA) yang signifikan sebelum dan sesudah Joko Widodo ditetapkan sebagai Presiden terpilih Indonesia pada perusahaan yang listing di Jakarta Islamic Index?

Adapun tujuan yang ingin dicapai dari penelitian ini adalah untuk mengetahui dan menganalisis apakah terdapat Average Abnormal Return (AAR) yang signifikan disekitar tanggal penetapan Joko Widodo sebagai Presiden terpilih Indonesia pada perusahaan yang listing di Jakarta Islamic Index serta untuk mengetahui dan menganalisis apakah terdapat perbedaan Abnormal Trading Volume Activity (ATVA) yang signifikan sebelum dan sesudah Joko Widodo ditetapkan sebagai Presiden terpilih Indonesia pada perusahaan yang listing di Jakarta Islamic Index.

\section{LANDASAN TEORI}

Husnan (2009:260) mendefinisikan pasar modal yang efisien sebagai pasar yang harga sekuritas-sekuritasnya telah mencerminkan semua informasi yang relevan. Dalam teori pasar efisien, pasar terdiri atas pasar efisien bentuk kuat, setengah kuat, dan lemah. Penelitian ini termasuk dalam pengujian bentuk pasar efisien setengah kuat, yaitu pasar dimana harga-harga sekuritas secara penuh mencerminkan (fully reflect) semua informasi yang dipublikasikan (all publicly available information) termasuk informasi yang berada di laporan-laporan keuangan perusahaan emiten (Fama (1970) dalam Hartono, 2013:548). Informasi yang dipublikasikan dalam penelitian ini adalah pengumuman hasil pemilu presiden 2014 yang menyatakan kemenangan Joko Widodo.

Pasar efisien setengah kuat diuji dengan menggunakan event study, yaitu studi yang mempelajari reaksi pasar terhadap suatu peristiwa (event) yang informasinya dipublikasikan sebagai pengumuman (Hartono, 2013:585). Reaksi pasar merupakan respons pasar terhadap suatu peristiwa yang mengandung informasi ekonomi. Reaksi pasar tercermin pada adanya abnormal return di sekitar tanggal publikasi peristiwa dan adanya perbedaan trading volume activity sebelum dan sesudah tanggal publikasi peristiwa.

Pasar dalam Islam juga dituntut untuk berjalan dengan efisien, semua pemegang kepentingan dalam pasar modal memiliki informasi yang sama dan mengambil tindakan yang sama, sehingga tindakan satu investor tidak dapat mempengaruhi perubahan harga- 
harga saham di pasar modal. Hal ini bertujuan untuk melindungi transaksi saham dari kegiatan-kegiatan yang bersifat spekulatif.

\section{METODE PENELITIAN}

Metode yang digunakan dalam penelitian ini adalah metode event study, yaitu menganalisis reaksi pasar atas suatu informasi atau peristiwa yang dipublikasikan. Oleh karena itu, variabelvariabel yang diteliti meliputi peristiwa, yaitu pengumuman kemenangan Joko Widodo, dan reaksi pasar yang diproksikan dengan average abnormal return dan abnormal trading volume activity.

Populasi dalam penelitian ini adalah saham-saham yang tergabung dalam Jakarta Islamic Index. Teknik pengambilan sampel yang digunakan adalah judgment sampling dengan kriteria:

1. Perusahaan tetap listing selama periode estimasi, yaitu MaretSeptember 2014.

2. Selama pengamatan perusahaan memiliki data yang lengkap untuk digunakan dalam penelitian ini. Data yang dibutuhkan antara lain indeks harga saham gabungan, harga saham harian pada saat penutupan perdagangan (closing price), serta data volume perdagangan saham harian.

\section{Definisi Operasional}

1. Peristiwa (event) pengumuman kemenangan Joko Widodo sebagai Presiden terpilih Indonesia
Salah satu faktor eksternal (lingkungan makro) yang dapat mempengaruhi perubahan harga saham adalah gejolak politik. Peristiwa pengumuman kemenangan Joko Widodo sebagai Presiden terpilih Indonesia merupakan salah satu gejolak politik yang idealnya dapat mempengaruhi keputusan investor dalam melakukan investasi. Pengumuman kemenangan Joko Widodo sebagai Presiden dapat berimplikasi pada reaksi pasar yang positif maupun negatif tergantung pada bagaimana para investor menangkap informasi tersebut sebagai berita baik atau buruk. Peristiwa pengumuman kemenangan Joko Widodo sebagai Presiden terpilih Indonesia yang jatuh pada tanggal 21 Agustus 2014 merupakan event date dalam event study ini. Variabel ini merupakan acuan pengukuran variabel lainnya dimana harga saham saat event date dinyatakan dalam t-0.

\section{Rata-rata abnormal return (AAR)}

Average abnormal return merupakan rata-rata abnormal return yang sedang dianalisis. Average Abnormal Return dihitung menggunakan rumus:

$A A R_{t}=\frac{\sum A R_{t}}{n}$

$\mathrm{AAR}_{\dagger}$ : rata-rata abnormal return pada periode ke- $\dagger$

$\mathrm{AR}_{\dagger} \quad$ : abnormal return saham pada periode peristiwa ke- $\dagger$

n : jumlah sampel/jumlah emiten yang diamati 
3. Abnormal Trading Volume Activity (ATVA)

Abnormal trading volume activity adalah abnormal volume perdagangan saham oleh investor yang digunakan untuk melihat adanya reaksi pasar modal atau perubahan harga saham terhadap informasi yang dipublikasikan. ATVA dapat dihitung dengan menggunakan rumus sebagai berikut:

$\operatorname{ATV}_{\uparrow}=$ Actual TVA $_{t}-$ expected TVA $A_{t}$

ATVA $_{\dagger} \quad:$ volume perdagangan abnormal yang terjadi pada hari ke- $\dagger$

Actual TVA $A_{\dagger}$ : volume perdagangan yang terjadi pada hari ke- $\dagger$

Expected TVA $A_{t}$ : volume perdagangan yang diharapkan pada hari ke- $\dagger$

\section{Jenis dan Sumber Data}

Jenis dan sumber data yang digunakan adalah data sekunder berupa data tanggal pengumuman, data perusahaan yang listing di Jakarta Islamic Index, data indeks harga saham gabungan, data harga saham harian, serta data volume perdagangan harian.

Data diperoleh dengan mengakses website www.idx.co.id, www.finance.yahoo.com, dan www.kpu.go.id serta sumber-sumber lain yang relevan berupa buku literatur, penelitian terdahulu, dan artikel dari internet.

\section{Teknik Pengumpulan Data}

Prosedur pengumpulan data yang dilakukan dalam penelitian ini melalui tahap-tahap berikut:

1. Tahap pertama dilakukan studi kepustakaan dengan mengumpulkan teori-teori pendukung dari literatur dan penelitian-penelitian terdahulu guna mendapatkan literatur yang diperlukan dalam kajian teori sebagai alternatif pemecahan masalah yang menjadi bahasan dalam penelitian ini.

2. Tahap kedua adalah pengumpulan data-data sekunder yang diperlukan, yaitu data perusahaan yang listing di Jakarta Islamic Index. Data sekunder lainnya yang diperlukan adalah sebagai berikut:

a. Data saham yang dikeluarkan perusahaan yang listing di Jakarta Islamic Index diperoleh dari www.finance.yahoo.com periode Maret-September 2014

b. Tanggal pengumuman kemenangan Joko Widodo sebagai Presiden terpilih Indonesia oleh Mahkamah Konstitusi. Penelitian ini dilakukan dengan periode estimasi lestimation period) selama 100 hari dan periode pengamatan levent windows) selama 21 hari, yakni 10 hari sebelum peristiwa, hari pengumuman kemenangan Joko Widodo, serta 10 hari setelah peristiwa $\left(t_{-10}, t_{0}\right.$, dan $\left.t_{+10}\right)$. Pada saat periode pengamatan levent windows) saham emiten yang diteliti, tidak terdapat kejadian lain yang sama waktunya seperti stock split, saham bonus, dan lain-lain untuk menghindari confounding effect yang akan mempengaruhi 
harga dan volume perdagangan saham (trading volume activity).

c. Data volume perdagangan saham perusahaan yang listing di Jakarta Islamic Index periode MaretSeptember 2014.

\section{Teknik Analisis Data}

Metode yang digunakan dalam penelitian ini adalah event study. Periode uji dilakukan selama 121 hari perdagangan (trading days) yaitu 100 hari periode estimasi (estimation period) dan 21 hari periode pengamatan levent windows) yang terdiri atas 10 hari sebelum peristiwa $\left(t_{-10}\right)$, hari peristiwa $\left(t_{0}\right)$, serta 10 hari setelah peristiwa $\left(t_{+10}\right)$ pengumuman kemenangan Joko Widodo sebagai Presiden Republik Indonesia oleh Mahkamah Konstitusi. Model yang digunakan adalah market model (model pasar), hal ini dikarenakan penelitian ini menggunakan periode estimasi. Penelitian ini mengamati perubahan harga saham yang ditunjukkan dengan adanya abnormal return di sekitar tanggal pengumuman kemenangan Joko Widodo dan perbedaan tingkat trading volume activity (TVA) sebelum dan sesudah pengumuman kemenangan Joko Widodo.

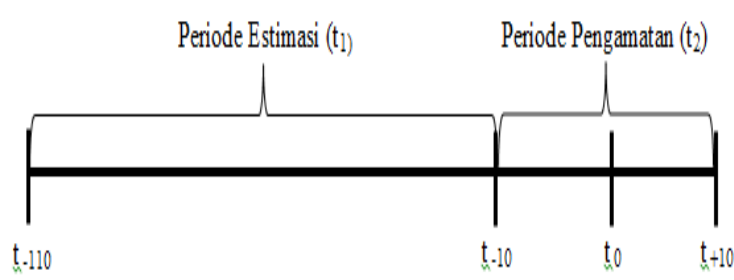

Gambar 1.

Periode Penelitian
Langkah-langkah dalam teknis analisis data adalah sebagai berikut:

1. Menghitung actual return saham individual (Rit) selama waktu pengamatan dengan menggunakan rumus:

$R_{i, t}=\left[\frac{P_{i, t}-P_{i, t-1}}{P_{i, t-1}}\right]$

Keterangan:

$\mathrm{R}_{\mathrm{i}, \mathrm{t}}=$ Return aktual saham i periode $\dagger$

$\mathrm{P}_{\mathrm{i}, \mathrm{t}}=$ harga saham $\mathrm{i}$ periode $\dagger$

$\mathrm{P}_{\mathrm{i}, \mathrm{t}-\mathrm{l}}=$ harga saham i periode $\mathrm{t}-1$

2. Menghitung return pasar harian selama periode pengamatan dengan menggunakan rumus:

$R_{m t}=\left[\frac{I H S G_{t}-I H S G_{t-1}}{I H S G_{t-1}}\right]$

Keterangan:

$\mathrm{R}_{\mathrm{mt}}=$ Return pasar pada periode $\dagger$

IHSG $\quad=$ Indeks Harga

Saham Gabungan pada periode †

IHSGt-1 = Indeks Harga Saham

Gabungan pada periode $\mathrm{t}-1$

3. Menghitung expected return dengan menggunakan model pasar (market model). Model ini memprediksi $E\left(R_{i, t}\right)$ berdasarkan hasil estimasi model pasar selama periode estimasi dengan persamaan sebagai berikut:

$E\left(R_{i, t)}=\alpha_{i}+\beta_{i} \cdot R_{m, t}+\varepsilon_{i, t}\right.$

Keterangan:

$\mathrm{E}\left(\mathrm{R}_{\mathrm{i}, \mathrm{t}}\right) \quad=$ Return ekspektasi saham $\mathrm{i}$ pada periode estimasi ke- $\dagger$

$a_{i}=$ intercept untuk saham $\mathrm{i}$

$\beta_{i}=$ koefisien slope yang merupakan Beta dari saham i

$R_{m, t}=$ Return indeks pasar pada periode estimasi ke- $\dagger$ 
$\varepsilon_{i, t}=$ kesalahan residu saham i pada periode estimasi ke- $\dagger$

4. Menghitung abnormal return:

$A R_{i, t}=R_{i, t}-E\left[R_{i, t}\right]$

Keterangan:

$\mathrm{AR}_{\mathrm{i}, \mathrm{t}}=$ return tak normal (abnormal return) saham i pada periode $\dagger$

$\mathrm{R}_{\mathrm{i}, \mathrm{t}}=$ return riil saham $\mathrm{i}$ periode $\dagger$

$\mathrm{E}\left[\mathrm{R}_{\mathrm{i},}\right]=$ = return ekspektasi saham $\mathrm{i}$ periode $\dagger$

5. Menghitung rata-rata abnormal return:

$A A R_{t}=\frac{\sum A R_{t}}{n}$

Keterangan:

$\mathrm{AAR}_{\dagger} \quad=$ rata-rata abnormal return pada periode ke- $\dagger$

$A R_{\dagger}=$ abnormal return saham pada periode peristiwa ke- $\dagger$

$\mathrm{n}=$ jumlah sampel/jumlah emiten yang diamati

6. Menghitung kesalahan standar estimasi (KSE) berdasarkan rata-rata return periode estimasi dengan persamaan:

$K S E_{i}=\sqrt{\frac{\sum_{t=t 1}^{t 2}\left(R_{i, t}-\bar{R}\right)^{2}}{t_{1}-2}}$

Keterangan:

$\mathrm{KSE}_{\mathrm{i}}=$ kesalahan standar estimasi untuk sekuritas ke-i

$\mathrm{R}_{\mathrm{i}, \mathrm{t}} \quad=$ return sekuritas ke-i hari ke- $\dagger$ selama periode estimasi

$\bar{R}=$ rata-rata return sekuritas

ke-i selama periode estimasi

$\dagger_{1}=$ jumlah hari di periode estimasi, yaitu hari ke-t-110 sampai dengan hari ke $t_{-10}$
7. Menghitung standardized abnormal return (SAR) dengan rumus:

$S A R_{i, t}=\frac{A R_{i, t}}{K S E_{i}}$

$S A R_{t}=\frac{\sum_{i}^{n} S A R_{i, t}}{\sqrt{n}}$

Keterangan:

$S A R_{i, t}=$ return taknormal standardisasi sekuritas ke-i untuk hari ke-t pada periode pengamatan $\mathrm{SAR}_{\dagger}=$ return taknormal standardisasi portofolio untuk hari ke- $\dagger$ pada periode pengamatan $\mathrm{n}=$ jumlah sampel/jumlah emiten yang diamati

8. Menghitung actual trading volume activity:

$T V A_{t}=\frac{\text { Jumlah saham perusahaan i yang diperdagangkan pada hari } k \theta-t}{\text { Jumlah saham perusahaan i yang tercatat di BEl pada hari } k \theta-t}$

9. Menghitung expected trading volume activity atau volume perdagangan yang diharapkan menggunakan metode market adjusted model:

Expected $T V A_{t}=\frac{\text { Totalvolume perdagangansemua emiten pada har } k \mathrm{k}-\mathrm{t}}{\text { Total jumlah saham yang ber sdar di pasar pada har } \mathrm{k} \varepsilon-t}$.

10. Menghitung abnormal trading volume activity:

Abnormal TVA $A_{t}=$ actual TVA $_{t}-$ expected TVA $_{t}$

Keterangan:

Abnormal TVAt $=\quad$ volume perdagangan abnormal yang terjadi pada

hari ke- $\dagger$

Actual TVA $A_{\dagger} \quad=\quad$ volume perdagangan yang terjadi pada hari ke- $\uparrow$ 
Expected TVA $A_{t} \quad$ volume perdagangan yang diharapkan hari ke- $\dagger$

11. Melakukan uji-† untuk data average abnormal return harian selama periode pengamatan. Uji one sample t-test digunakan untuk melihat signifikansi average abnormal return selama periode pengamatan dari perusahaan yang listing di JII.

Langkah-langkah dalam uji-† adalah sebagai berikut:

a. Merumuskan hipotesis terhadap $A A R_{\dagger}$ $\mathrm{H}_{0.1}: \mathrm{AAR}_{t}=0$ : terdapat average abnormal return (AAR) yang tidak signifikan di sekitar tanggal pengumuman kemenangan Joko Widodo.

$\mathrm{H}_{0.2}: \mathrm{AAR}_{\dagger} \neq 0$ : terdapat average abnormal return (AAR) yang signifikan di sekitar tanggal pengumuman kemenangan Joko Widodo.

b. Menentukan tingkat signifikansi (a) = $5 \%$

c. Melakukan pengujian AAR dengan uji one sample t-test dengan persamaan: $t=\frac{A A R_{t}}{S_{t} / \sqrt{n}}$ Keterangan:

$S_{\dagger}=$ Standar deviasi AAR saham pada periode ke- $\dagger$

$\mathrm{n}$ = Jumlah emiten yang diamati

Besarnya standar deviasi dihitung dengan rumus:

$S=\sqrt{S^{2}}$

$S^{2}=\frac{n \sum x_{i}^{2}-\left(\sum x_{i}\right)^{2}}{n-(n-1)}$

Keterangan:
$\mathrm{S}^{2}=$ varians sampel

$S$ = standar deviasi sampel

$\mathrm{x}_{\mathrm{i}}$ = besarnya data tiap sampel

$\mathrm{n}=$ jumlah sampel/jumlah emiten yang diamati

d. Kriteria pengujian:

$\mathrm{H}_{0.1}$ diterima apabila $t_{\text {value }} \geq(a)=5 \%$

$\mathrm{H}_{0.2}$ diterima apabila $\mathrm{t}_{\text {value }}<(\mathrm{a})=5 \%$

12. Melakukan uji paired sample t-test untuk data average abnormal trading volume activity dengan tujuan melihat signifikansi volume abnormal return perdagangan saham selama periode pengamatan dari perusahaan yang listing di JII.

Langkah-langkah dalam uji paired sample t-test sebagai berikut:

a. Merumuskan hipotesis terhadap ATVA $A_{t}$ $H_{1.1}:$ ATVA $_{t}=0$ : terdapat perbedaan abnormal trading volume activity yang tidak signifikan sebelum dan sesudah pengumuman kemenangan Joko Widodo.

$\mathrm{H}_{1.2}$ : ATV $A_{\uparrow} \neq 0$ : terdapat perbedaan abnormal trading volume activity yang signifikan sebelum dan sesudah pengumuman kemenangan Joko Widodo.

b. Menentukan tingkat signifikansi (a) = $5 \%$

c. Melakukan pengujian ATVA dengan uji paired sample t-test dengan persamaan:

$t=\frac{A T V A_{t}}{S_{t} / \sqrt{n}}$

Keterangan:

$\mathrm{S}_{\dagger}=$ Standar deviasi ATVA saham pada periode ke- $\dagger$ 
$\mathrm{n}$ = Jumlah emiten yang diamati

Besarnya standar deviasi dihitung dengan rumus:

$S=\sqrt{S^{2}}$

$S^{2}=\frac{n \sum x_{i}^{2}-\left(\sum x_{i}\right)^{2}}{n-(n-1)}$

Keterangan:

$\mathrm{S}^{2}=$ varians sampel

$S$ = standar deviasi sampel

$x_{i}=$ besarnya data tiap sampel

$\mathrm{n}=$ jumlah sampel/jumlah emiten yang diamati

d. Kriteria pengujian:

$\mathrm{H}_{1.1}$ diterima apabila tvalue $\geq(\mathrm{a})=5 \%$

$\mathrm{H}_{1.2}$ diterima apabila tvalue $<(\mathrm{a})=5 \%$

\section{HASIL DAN PEMBAHASAN}

\section{Analisis Average Abnormal Return Pada Pengamatan Harian}

Dari hasil penghitungan statistik dengan alat bantu uji program SPSS ver.17, diperoleh hasil output one sample t-test pada average abnormal return disajikan dalam tabel berikut:

\section{Tabel 1.}

Hasil Uji Statistik Average Abnormal Return (AAR) one sample t-Test

\begin{tabular}{|c|c|c|c|c|}
\hline \multirow{2}{*}{$\begin{array}{c}\text { Event } \\
\text { Window }\end{array}$} & \multirow{2}{*}{$\begin{array}{c}\text { Average } \\
\text { Abnormal } \\
\text { Return } \\
\text { (AAR) }\end{array}$} & \multicolumn{2}{|c|}{ Test Value $=0$} & \multirow{2}{*}{ Keterangan } \\
\hline & & $\begin{array}{c}\text { Sig. } \\
(2- \\
\text { tailed) }\end{array}$ & $t$ & \\
\hline$t-10$ & -0.0019 & 0.507 & -0.673 & diterima \\
\hline t-9 & -0.0015 & 0.544 & -0.616 & diterima \\
\hline$t-8$ & -0.0003 & 0.919 & -0.103 & diterima \\
\hline$t-7$ & -0.0005 & 0.864 & -0.173 & diterima \\
\hline$t-6$ & 0.0043 & 0.070 & 1.894 & diterima \\
\hline$t-5$ & 0.0002 & 0.958 & 0.053 & diterima \\
\hline$t-4$ & 0.0014 & 0.641 & 0.472 & diterima \\
\hline$t-3$ & 0.0033 & 0.369 & 0.915 & diterima \\
\hline$t-2$ & -0.0016 & 0.564 & -0.585 & diterima \\
\hline$t-1$ & -0.0017 & 0.461 & -0.750 & diterima \\
\hline
\end{tabular}

\begin{tabular}{|c|c|c|c|c|}
\hline$t 0$ & -0.0033 & 0.238 & -1.211 & diterima \\
\hline$t+1$ & -0.0020 & 0.443 & -0.781 & diterima \\
\hline$t+2$ & -0.0033 & 0.225 & -1.246 & diterima \\
\hline$t+3$ & -0.0040 & 0.266 & -1.139 & diterima \\
\hline$t+4$ & 0.0010 & 0.767 & 0.299 & diterima \\
\hline$t+5$ & -0.0005 & 0.811 & -0.241 & diterima \\
\hline$t+6$ & -0.0002 & 0.950 & -0.063 & diterima \\
\hline$t+7$ & 0.0014 & 0.728 & 0.352 & diterima \\
\hline$t+8$ & 0.0015 & 0.588 & 0.549 & diterima \\
\hline$t+9$ & 0.0059 & 0.008 & 2.880 & ditolak \\
\hline$t+10$ & -0.0066 & 0.069 & -1.905 & diterima \\
\hline
\end{tabular}

Sumber: Hasil penelitian, diolah (2015)

Selama periode pengamatan 21 hari perdagangan, yaitu t-10 sampai dengan ++10 mayoritas data memiliki nilai probabilitas yang lebih besar dari $(a)=5 \%$. Pada periode $t-10$ sampai dengan periode $t+8$, kemudian pada $t+10$ average abnormal return memiliki nilai probabilitas yang lebih besar dari $(a)=5 \%$ atau 0.05, sehingga $\mathrm{H}_{0}$ diterima dan $\mathrm{H}_{1}$ ditolak. Hal ini menunjukkan terdapat average abnormal return yang tidak signifikan di sekitar tanggal pengumuman kemenangan Joko Widodo.

Dari hasil pengujian statistik di atas maka dapat disimpulkan pasar tidak bereaksi signifikan atas peristiwa pengumuman kemenangan Joko Widodo yang ditunjukkan dengan adanya average abnormal return yang tidak signifikan di sekitar tanggal pengumuman. Hal ini dimungkinkan karena pasar sudah mengantisipasi lebih dahulu informasi yang terkandung dalam pengumuman dimana pengumuman yang dijadikan event date dalam penelitian merupakan pengumuman kedua kemenangan Joko Widodo setelah sebelumnya pada tanggal 22 Juli 2014 pengumuman atas 
kemenangan Joko Widodo sebagai Presiden terpilih tidak diterima oleh pihak calon presiden nomor urut satu, yaitu Prabowo. Hal ini menyebabkan dilakukannya sidang penghitungan suara ulang dan hasilnya diumumkan pada tanggal 21 Agustus 2014 yang dalam penelitian ini dijadikan sebagai event date.

Penghitungan secara manual dengan menggunakan bantuan program Microsoft Excel 2010 juga menunjukkan hasil yang tidak signifikan seperti yang termuat pada tabel 2 di bawah ini.

Tabel 2.

Hasil Uji Statistik Average Abnormal Return (AAR) Manual

\begin{tabular}{|c|c|c|}
\hline $\begin{array}{c}\text { Event } \\
\text { Window }\end{array}$ & $\begin{array}{c}\text { Average } \\
\text { Abnormal Return } \\
\text { (AAR) }\end{array}$ & t-hitung \\
\hline$t-10$ & -0.0019 & -0.4830 \\
\hline$t-9$ & -0.0015 & -0.5270 \\
\hline$t-8$ & -0.0003 & 0.0240 \\
\hline$t-7$ & -0.0005 & -0.1594 \\
\hline$t-6$ & 0.0043 & 1.0937 \\
\hline$t-5$ & 0.0002 & 0.0580 \\
\hline$t-4$ & 0.0014 & 0.3321 \\
\hline$t-3$ & 0.0033 & 0.7697 \\
\hline$t-2$ & -0.0016 & -0.7779 \\
\hline$t-1$ & -0.0017 & -0.1486 \\
\hline$t 0$ & -0.0033 & -0.6799 \\
\hline$t+1$ & -0.0020 & -0.5285 \\
\hline$t+2$ & -0.0033 & -0.5618 \\
\hline$t+3$ & -0.0040 & -0.8033 \\
\hline$t+4$ & 0.0010 & 0.0480 \\
\hline$t+5$ & -0.0005 & -0.0969 \\
\hline$t+6$ & -0.0002 & -0.3626 \\
\hline$t+7$ & 0.0014 & 1.0078 \\
\hline$t+8$ & 0.0015 & 0.2641 \\
\hline & & \\
\hline
\end{tabular}

\begin{tabular}{|c|c|c|}
\hline${ }^{\dagger+9}$ & 0.0059 & 1.3725 \\
\hline$\dagger+10$ & -0.0066 & -1.8061 \\
\hline \multicolumn{2}{|c|}{$\begin{array}{c}\text { Signifikan pada tingkat 5\% ( }>\text { > 2.064 untuk } \\
\text { pengujian dua sisi dengan df }=24)\end{array}$} \\
\hline
\end{tabular}

Sumber: Hasil penelitian, diolah (2015)

Penghitungan secara manual juga dilakukan karena Tandelilin (2010:576) menyatakan bahwa pendekatan yang digunakan dalam uji ini berbeda dari model biasa sehingga program komputer statistik seperti SPSS tidak dapat digunakan dalam pengujian. Namun demikian, hasil yang ditunjukkan tidak berbeda dengan hasil dari program SPSS. Terlihat dalam tabel 2 di atas semua nilai thitung menunjukkan nilai yang lebih kecil dari t-tabel (2.064) sehingga nilai tidak signifikan pada tingkat signifikansi $(a)=5 \%$. Terdapatnya average abnormal return yang tidak signifikan pada semua spot waktu di seputar pengumuman peristiwa kemenangan Joko Widodo menunjukkan bahwa pasar tidak bereaksi atau tidak mempercayai informasi yang terkandung dalam peristiwa pengumuman kemenangan Joko Widodo.

\section{Analisis Average Trading Volume Activity}

\section{Pada Pengamatan Harian}

Dari hasil penghitungan statistik dengan alat bantu Uji program SPSS ver.17, diperoleh hasil output paired sample t-test pada average abnormal trading volume activity disajikan dalam tabel berikut:

Tabel 3.

Hasil Uji Statistik Paired t-Test Correlation Pada Average Abnormal Trading Volume Activity (AATVA) 


\begin{tabular}{|c|c|c|}
\hline & $\begin{array}{c}\text { AATVA } \\
\text { sebelum } \\
\text { pengumuman }\end{array}$ & $\begin{array}{c}\text { AATVA } \\
\text { sesudah } \\
\text { pengumuman }\end{array}$ \\
\hline Mean & 0.00006770 & 0.00018130 \\
\hline $\begin{array}{c}\text { Standar } \\
\text { Deviasi }\end{array}$ & 0.000046630 & 0.000038225 \\
\hline$t$ & \multicolumn{2}{|c|}{-2.209} \\
\hline df & \multicolumn{2}{|c|}{9} \\
\hline $\begin{array}{c}\text { Sig. (2- } \\
\text { tailed) }\end{array}$ & \multicolumn{2}{|c|}{055} \\
\hline Keterangan & \multicolumn{2}{|c|}{ Tidak Signifikan } \\
\hline
\end{tabular}

Sumber: Hasil penelitian, diolah (2015)

Tabel 3 di atas menunjukkan bahwa AATVA selama 10 hari sebelum peristiwa pengumuman kemenangan Joko Widodo ( $t_{-10}$ sampai $\left.t_{-1}\right)$ diperoleh sebesar 0.00006770 atau terjadi perdagangan saham oleh emiten sebesar $0.00677 \%$ dari seluruh saham yang ada, sedangkan setelah peristiwa pengumuman kemenangan Joko Widodo $\left(t_{+1}\right.$ sampai $\left.t_{+10}\right)$ AATVA diperoleh sebesar 0.00018130 atau terjadi perdagangan saham oleh emiten sebesar $0.01813 \%$ dari seluruh saham yang ada. AATVA sesudah pengumuman kemenangan Joko Widodo lebih besar dibandingkan AATVA sebelum pengumuman, secara matematis hal ini menunjukkan adanya reaksi pasar yang dilakukan para investor terkait peristiwa pengumuman kemenangan Joko Widodo.

Namun demikian, hasil pengujian perbedaan average abnormal trading volume activity saham Jll sebelum dan sesudah peristiwa pengumuman kemenangan Joko Widodo secara statistik diperoleh $t=-2.209$ dengan signifikansi sebesar 0.055 atau berada di atas 0.05. Hal ini berarti terdapat perbedaan yang tidak signifikan pada average abnormal trading volume activity (AATVA) saham JII sebelum dan sesudah pengumuman kemenangan Joko Widodo. Adanya perbedaan yang tidak signifikan pada average abnormal trading volume activity ini dimungkinkan karena investor sudah lebih dulu mengantisipasi kandungan informasi dan dampak dari terpilihnya Joko Widodo. Hal ini dikarenakan pengumuman kemenangan Joko Widodo ini merupakan pengumuman kedua terkait adanya penolakan dari kubu Prabowo yang tidak menerima hasil pengumuman kemenangan Joko Widodo yang pertama, yaitu pada tanggal 22 Juli 2014, sehingga para investor memiliki rentang waktu yang cukup untuk mempersiapkan keputusan apa yang akan diambil untuk menghadapi pengumuman berikutnya yang kemungkinan besar masih sama dengan pengumuman pertama.

Dari hasil penelitian tersebut, menunjukkan bahwa sebelum dan sesudah peristiwa pengumuman kemenangan Joko Widodo sebagai Presiden terpilih Indonesia oleh Mahkamah Konstitusi terdapat perubahan reaksi perdagangan saham yang tidak signifikan. Dengan demikian $\mathrm{H}_{0}$ diterima dan $\mathrm{H}_{1}$ ditolak.

\section{Pembahasan}

Pembahasan hasil penelitian didasarkan pada uji one sample t-test untuk menguji hipotesis tentang reaksi 
saham perusahaan yang terdaftar dalam Jakarta Islamic Index atas peristiwa pengumuman kemenangan Joko Widodo sebagai Presiden terpilih Indonesia serta uji paired sample t-test untuk menguji perbedaan aktivitas volume perdagangan saham sebelum dan sesudah tanggal pengumuman.

Penelitian ini mencoba menganalisis kandungan informasi yang termuat pada peristiwa pengumuman kemenangan Joko Widodo sebagai Presiden terpilih Indonesia. Ada tidaknya kandungan informasi tercermin pada reaksi pasar yang diproksikan oleh ada tidaknya abnormal return di sekitar tanggal pengumuman dan ada tidaknya perbedaan trading volume activity sebelum dan sesudah tanggal pengumuman.

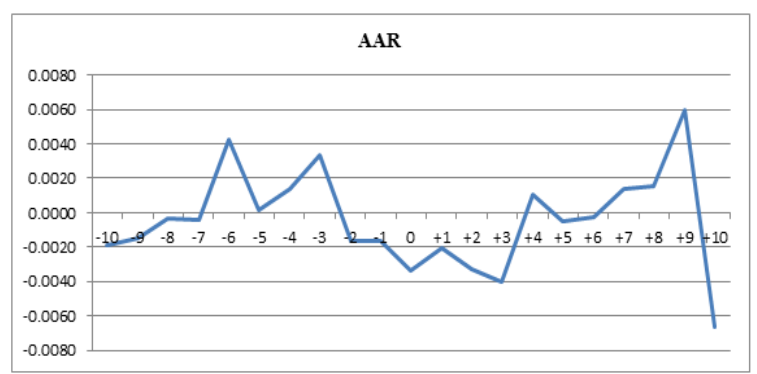

Gambar 2.

Grafik Average Abnormal Return (AAR) seluruh Emiten Pada Periode Pengamatan Pada gambar 2 di atas terlihat pergerakan AAR yang cenderung fluktuatif dengan range yang cukup lebar antar hari selama periode pengamatan. Selama 21 hari periode pengamatan AAR positif terjadi sebanyak delapan kali, yaitu pada $t-6$ sampai dengan $t-3$, pada $t+4$, serta pada periode pengamatan $t+7$ sampai dengan t+9 dan AAR negatif terjadi sebanyak 13 kali, yaitu pada t-10 sampai dengan t-7, pada t-2 sampai dengan $t+3$, pada $t+5, t+6$, serta $t+10$. $\mathrm{Hal}$ ini menunjukkan bahwa dari seluruh emiten yang diteliti, sebagian besar memiliki rata-rata abnormal return yang nilainya lebih kecil dari nol atau bernilai negatif, artinya rata-rata expected return lebih besar dibandingkan rata-rata actual return.

Reaksi negatif cukup besar terjadi tepat sebelum pengumuman ( $\mathrm{t}-2$ sampai dengan t-1), saat pengumuman (t0), serta setelah pengumuman $(t+1$ sampai dengan ++3 ). Hal ini menunjukkan bahwa pasar menganggap peristiwa pengumuman kemenangan Joko Widodo sebagai Presiden terpilih Indonesia memberikan sinyal tentang adanya informasi buruk terhadap aktivitas bursa, dimana dapat menimbulkan risiko, baik risiko sistematis maupun risiko tidak sistematis bagi investor dan bagi investasinya (bad news). Pada $t+4, t+7$, $t+8, t+9$ sempat terjadi reaksi positif yang cukup besar, hal ini dimungkinkan terjadi karena adanya beberapa investor yang melakukan evaluasi kandungan informasi atas pengumuman kemenangan Joko Widodo.

Secara deskriptif dari gambar 2 di atas terlihat adanya reaksi pasar di sekitar pengumuman yang ditunjukkan dengan nilai average abnormal return yang tidak sama dengan nol. Namun demikian, hasil uji statistik menunjukkan hasil yang tidak signifikan yang ditunjukkan oleh nilai probabilitas mayoritas data yang lebih 
dari 0.05, hal ini berarti terdapat average abnormal return yang tidak signifikan di sekitar tanggal pengumuman kemenangan Joko Widodo atau dengan kata lain pasar tidak bereaksi atas pengumuman.

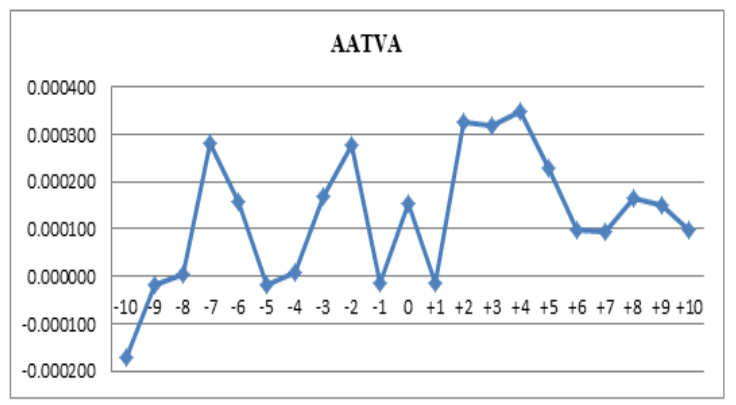

Gambar 3.

Grafik Average Abnormal Trading Volume Activity (AATVA) seluruh Emiten Pada Periode Pengamatan

Pada gambar 3 di atas terlihat adanya reaksi pasar sebelum dan sesudah tanggal pengumuman yang ditunjukkan dengan adanya average abnormal trading volume activity yang tidak sama dengan nol. Dari gambar di atas juga terlihat adanya perbedaan average abnormal trading volume activity dimana nilai average abnormal trading volume activity setelah pengumuman lebih besar dibandingkan sebelum pengumuman, akan tetapi perubahan tidak signifikan atau tidak terlalu mencolok. Hal ini sejalan dengan hasil penelitian terhadap average abnormal trading volume activity dengan melihat hasil uji statistik paired sample t-test, terdapat perbedaan yang tidak signifikan pada trading volume activity saham pada sebelum dan sesudah pengumuman kemenangan Joko Widodo sebagai
Presiden terpilih Indonesia, ditunjukkan dengan nilai probabilitas sebesar 0.055.

Dari kedua variabel yang diteliti menunjukkan adanya reaksi pasar yang tidak signifikan di sekitar tanggal pengumuman kemenangan Joko Widodo. Hal ini merefleksikan bahwa pelaku pasar (investor) telah mengantisipasi peristiwa pengumuman kemenangan Joko Widodo sebagai Presiden terpilih Indonesia ini sehingga investor tidak terburu-buru dalam pengambilan keputusan untuk melakukan aktivitas jual-beli saham. Dengan demikian, penelitian ini memenuhi asumsi hipotesis pasar efisien bentuk setengah kuat karena sebagian besar investor mendapatkan informasi yang sama dan bergerak secara bersama mengikuti perubahan yang terjadi yang ditunjukkan dengan nilai average abnormal return dan average abnormal trading volume activity yang tidak signifikan.

\section{v. SIMPULAN}

Berdasarkan hasil penelitian terkait dengan reaksi pasar atas terpilihnya Joko Widodo sebagai Presiden Republik Indonesia periode 2014-2019 yang dilakukan pada emiten atau perusahaan yang listed di Jakarta Islamic Index (JII), maka dapat diambil kesimpulan sebagai berikut:

1. Terdapat Average Abnormal Return (AAR) yang tidak signifikan di sekitar tanggal penetapan Joko Widodo sebagai Presiden terpilih Indonesia pada perusahaan yang listing di Jakarta Islamic Index. Dari hasil 
penghitungan secara statistik mayoritas data, yaitu 20 dari 21 hari pengamatan yang dilakukan memiliki nilai probabilitas yang lebih besar dari 0.05 sehingga $\mathrm{HO}$ diterima dan $\mathrm{HI}$ ditolak.

2. Terdapat perbedaan Abnormal Trading Volume Activity (ATVA) yang tidak signifikan sebelum dan sesudah Joko Widodo ditetapkan sebagai Presiden terpilih Indonesia pada perusahaan yang listing di Jakarta Islamic Index. Hasil penelitian terhadap abnormal trading volume activity dengan uji statistik paired sample t-test menunjukkan adanya perbedaan yang tidak signifikan pada trading volume activity saham sebelum dan sesudah pengumuman kemenangan Joko Widodo, dengan nilai probabilitas sebesar 0.055 .

Jadi dapat disimpulkan, reaksi pasar atas terpilinnya Joko Widodo sebagai Presiden Rl terpilih berdampak tidak signifikan terhadap Average Abnormal Return dan Abnormal Trading Volume Activity untuk saham-saham yang bergabung di Jakarta Islamic Index (JII).

\section{DAFTAR PUSTAKA}

Al-Qur'an

Anshori, Muslich dan Sri Iswati. 2009. Buku Ajar Metodologi Penelitian Kuantitatif. Surabaya: Airlangga University Press

Bodie, Zvi. Alex Kane dan Alan J. Marcus. 2014. Manajemen Portofolio dan Investasi: Investments. Edisi 9. Jakarta: Salemba Empat
Departemen Agama RI. 2004. Mushaf AlQur'an dan Terjemahnya Revisi tahun 2004. Jakarta: DEPAG R

Hartono, Jogiyanto. 2013. Teori Portofolio dan Analisis Investasi. Edisi Kedelapan. Yogyakarta: BPFE

Horne, James C. Van dan John $M$. Wachowicz, JR. 2005. Fundamentals of Financial Management: Prinsip-prinsip Manajemen Keuangan. Edisi 12. Jakarta: Salemba Empat

Huda, Nurul dan Mustafa Edwin Nasution. 2008. Investasi pada Pasar Modal Syariah. Jakarta: Kencana

Husnan, Suad. 2009. Dasar-Dasar Teori Portofolio \& Analisis Sekuritas. Edisi Keempat. Yogyakarta: UPP STM YKPN

Ryandono, Muhamad Nafik H. 2009. Bursa Efek \& Investasi Syariah. Jakarta: Serambi

Tandelilin, Eduardus. 2010. Portofolio dan Investasi: Teori dan Aplikasi. Edisi Pertama. Yogyakarta: Kanisius

Widarjono, Agus. 2010. Analisis Statistika Multivariat Terapan. Yogyakarta: UPP STIM YKPN

Yamin, Sofyan dan Heri Kurniawan. 2009. SPSS Complete: Teknik Analisis Statistik Terlengkap dengan Software SPSS. Jakarta: Salemba Infotek

Website:

www.bbc.co.uk diakses 08 September 2014

www.finance.yahoo.com diakses pada 09 September 2014

www.idx.co.id diakses pada 20 Desember 2014 
JESTT Vol. 2 No. 3 Maret 2015

www.kpu.go.id diakses pada 29

September 2014 